\title{
The effect of Mergers and Acquisitions on the technological performance of companies in a high- tech environment
}

Citation for published version (APA):

Duysters, G. M., \& Hagedoorn, J. (2002). The effect of Mergers and Acquisitions on the technological performance of companies in a high-tech environment. Technology Analysis \& Strategic Management, 14, 67-84. https://doi.org/10.1080/09537320220125892

Document status and date:

Published: 01/01/2002

DOI:

10.1080/09537320220125892

Document Version:

Publisher's PDF, also known as Version of record

Please check the document version of this publication:

- A submitted manuscript is the version of the article upon submission and before peer-review. There can be important differences between the submitted version and the official published version of record.

People interested in the research are advised to contact the author for the final version of the publication, or visit the DOI to the publisher's website.

- The final author version and the galley proof are versions of the publication after peer review.

- The final published version features the final layout of the paper including the volume, issue and page numbers.

Link to publication

\footnotetext{
General rights rights.

- You may freely distribute the URL identifying the publication in the public portal. please follow below link for the End User Agreement:

www.umlib.nl/taverne-license

Take down policy

If you believe that this document breaches copyright please contact us at:

repository@maastrichtuniversity.nl

providing details and we will investigate your claim.
}

Copyright and moral rights for the publications made accessible in the public portal are retained by the authors and/or other copyright owners and it is a condition of accessing publications that users recognise and abide by the legal requirements associated with these

- Users may download and print one copy of any publication from the public portal for the purpose of private study or research.

- You may not further distribute the material or use it for any profit-making activity or commercial gain

If the publication is distributed under the terms of Article $25 \mathrm{fa}$ of the Dutch Copyright Act, indicated by the "Taverne" license above, 


\title{
The Eff ect of Mergers and Acquisitions on the Technological Performance of Gompanies in a High-tech Environment
}

\section{JOHN HAGEDOORN \& GEERT DUYSTERS}

\begin{abstract}
A large part of the literature from industrial organization and management expects that, compared with unrelated MEAs, related MEAs show superior economic performance because of synergetic effects that follow from economies of scale and scope. The current contribution takes the debate on the effect of different MEAs somewhat further by studying the effect of MEAs on the technological performance of companies. In this study the technological performance of MEAs is related to a hightech sector, i.e. the international computer industry. The main result of this research is that the so-called strategic and organizational fit between companies involved in MEAs seem to play an important role in improving the technological performance of companies
\end{abstract}

\section{Introduction}

The central topic of this paper concerns the possible effect that mergers and acquisitions (M\&As) have on the technological performance of companies. This subject is clearly related, but not identical, to the more general question regarding the economic benefits (profitability) of M\&As. A number of influential industrial organization studies suggest that companies realize diminishing profitability for an extended period of time after an M\&A because of the cost of integration and poor performance of acquired units. ${ }^{1}$ However, other contributions ${ }^{2}$ suggest that long-term positive results for M\&As are found for diversification through M\&As across related product lines.

Largely inspired by Rumelt, ${ }^{3}$ the management literature has also moved away from a general evaluation of the economic performance of M\&As to an evaluation of different forms of M\&As, such as horizontal, vertical and unrelated M\&As. ${ }^{4}$ Although there is still considerable disagreement within the literature, a substantial part of it expects, primarily on theoretical grounds, that related M\&As show superior performance because of synergetic effects through economies of scale and scope.

In this contribution we will attempt to take the debate on M\&As somewhat further by studying their effect on the technological performance of companies in an international context. As indicated by Link, ${ }^{5}$ little research was done on this particular subject before the late-1980s. In recent years a small number of contributions to the management

John Hagedoorn is at MERIT, Faculty of Economics and Business Administration, University of Maastricht, PO Box 616, 6200 MD Maastricht, The Netherlands. Tel.: +31 43 3883897; Fax: +31 43 3254566; E-mail: j.hagedoorn@ mw.unimaas.nl. Geert Duysters is at ECIS, Faculty of Technology Management, Technological University Eindhoven, P.O. Box 5013, 5600MB Eindhoven, The Netherlands. Tel.: +31 40 2473972; Fax: +31 40 2468054; E-mail: G.M.Duysters@tm.tue.nl 
literature $^{6}$ have put this topic on the research agenda, although the international context has remained limited.

It is important to note that the technological performance of M\&As reflects the longterm effects of M\&As. Technology related incentives for M\&As affect long-term strategic variables which tend to be underestimated in much of the current empirical research, that usually focuses on the short-term, economic effects of M\&As. ${ }^{7}$ In these long-term effects the expected synergetic characteristics of M\&As can contribute to technological performance through the invention of new process-related technologies and new product-related technologies by the combined companies. These new technologies (inventions) can eventually lead to improved profitability of companies if they are transformed into actual innovations, i.e. new products and processes that are successfully introduced to the market. There can also be short-term effects of M\&As when the acquiring company intends to only obtain access to $\mathrm{R} \& \mathrm{D}$ and technological capabilities to simply produce an already existing, combined technological output. However, when these existing capabilities are used in the further development of new technological output, these short-term effects are expected to be limited in comparison to the long-term, synergetic technological effects of M\&As. This effect of merging companies is a well-known classic issue in the innovation literature ${ }^{8}$ where increased size of companies and synergies, through internal growth or by means of M\&As, are positively related to long-term technological performance.

The technological effect of M\&As is also discussed in some previous research on a related issue, i.e. the motivation for M\&As. Frequently mentioned motives for M\&As are: increased market share, improved efficiency, expanded R\&D efforts, investment adjustment, firm growth, risk reduction, speedy market entry. ${ }^{9}$ In older work on M\&As from the 1970s, increasing R\&D activities and improving technological performance seem hardly relevant as motives for M\&As. ${ }^{10}$ Technological motives for M\&As appear to be only moderately important across industries. ${ }^{11}$ However, other studies ${ }^{12}$ do suggest that M\&As are an important element in the technology acquisition strategy of companies, in particular in $R \& D$ intensive (high-tech) industries. We will continue along this line and study the effect of M\&As on technological performance in a high-tech sector, the computer industry. Obviously, M\&As are also important in other sectors but, as mentioned above, the relation between M\&As and technological performance is probably most evident in high-tech sectors.

In the following we will first outline a general perspective on the effect of M\&As on the technological performance of companies. This general perspective on M\&As and the related set of hypotheses stress the importance of understanding the conditions under which M\&As might have a positive effect on the technological performance of companies. In that context we will emphasize the role of strategic and organizational fit in explaining technological performance differentials. Although both play a substantial role in many analyses of M\&As and economic performance, strategic and organizational fit have received far less attention in much of the current work on M\&As, technological performance and related issues. Apart from this specific attention paid to the role of strategic and organizational fit in the technological performance of M\&As, a new element in our current contribution is the international setting of companies and their M\&As that goes beyond the boundaries of domestic markets. After the theoretical background and hypotheses have been explained, our paper continues with a discussion of our data, the variables and the measures used in this study. This is followed by sections in which the actual analysis, the discussion of the results and the conclusions from this paper are presented.

\section{Theoretical Background and Hypotheses}

In a number of seminal contributions to the literature, M\&As are seen as an important element in the overall strategy of companies to respond to uncertainty within the economy 
at large, uncertainty within particular industries, or uncertainty in the context of repeated transactions with other companies. ${ }^{13}$ The absorption of at least parts of their environment (i.e. other companies) by means of M\&As is one of the alternatives that companies have if they attempt to reduce uncertainty, increase their control over their environment or reduce their dependency on this environment. (Other mechanisms that are relevant but which are not discussed or analyzed in the context of our current research are strategic alliances that take the form of a variety of legal and organizational modes.) This absorption of other companies by means of M\&As in order to respond to uncertainty can take place through either the integration of other companies in sector(s) in which a company is already operating, or a diversification into another sector because the company has become too dependent on its existing environment. ${ }^{14}$ Studying M\&As from a more sector-specific perspective, some authors ${ }^{15}$ arrive at somewhat similar conclusions as M\&As are seen as a mechanism to increase control over the environment of companies in quickly changing, R\&D intensive, industries.

However, increasing control over the current or the new environment of companies cannot be taken as a goal in itself. The search for new, rewarding opportunities has to be part of this process of absorption of a company's environment. As a consequence, in order for a company to be successful, the objective of increasing control and integration by means of M\&As ultimately has to lead to improved performance. In the context of companies operating in a high-tech, $\mathrm{R} \& \mathrm{D}$ intensive environment, improved performance implies that integration by means of M\&As has to support the continuous search for new technological capabilities. We expect that if M\&As are successful, they enable companies to further develop new skills and improve their exploratory learning so as to increase the technological performance of companies. ${ }^{16}$

Following some suggestions in the literature ${ }^{17}$ we propose that in order to be successful not only in establishing M\&As, either in the current environment or in a new environment, but also to generate the expected results, M\&As are contingent upon both a 'strategic fit' and an 'organizational fit' that enable M\&A partners to collaborate in future activities. This implies that in order to achieve synergetic effects through M\&As, the strategic fit through market, product and technological complementarities or relatedness of companies has to be supplemented by an organizational fit in which the organizational structure of the merging companies appears to match. Effective control over parts of the environment by means of M\&As which also leads to improved performance is expected to be dependent on this strategic and organizational fit of the companies involved.

In the following we will discuss crucial elements of the strategic and organizational fit necessary to improve the technological performance of companies in a high-tech environment, separately. We reconstructed these elements of the strategic and organizational fit from the literature where these issues are analyzed in the broader context of the general performance of M\&As. ${ }^{18}$ These conditions for the success of synergetic M\&As are analyzed in terms of strategic fit related to the degree of the existing product-market relatedness of M\&As, the technological relatedness of M\&As and their organizational fit. These different elements of the fit between companies cover the current markets of companies, their present and future-oriented technological activities and the similarity in their organizational structure.

\section{Strategic Fit: Related and Unrelated MEAs}

In the literature one finds several categorizations of M\&As in terms of their 'relatedness' which usually can be traced back to the original classification scheme of the US Federal Trade Commission. ${ }^{19}$ Horizontal M\&As involve companies that are closely related as to 
the products or services they produce, i.e. both companies operate in the same productmarket. Vertical M\&As involve companies that had a potential or existing buyer-seller relationship prior to the M\&A. Conglomerate or unrelated M\&As involve essentially companies that are unrelated in terms of the product-markets in which they are operating and of which the M\&As are part of a widely diversifying strategy.

A substantial part of the literature seems to suggest that in general conglomerate M\&As are less successful than horizontally and vertically-related M\&As. ${ }^{20}$ As shown by Datta $^{21}$ there are also studies that find little or no evidence of such a relationship. On theoretical grounds, however, the idea that a strategic fit of companies, in terms of a relatedness of the product-markets in which companies are operating, remains appealing. Obviously, related M\&As are expected to profit from economies of scale and scope that should generate more synergetic benefits than in the case of unrelated M\&As that have no relationship other than becoming part of one overarching system of corporate control.

As our study focuses not on the economic performance of M\&As in general but on the specific issue of technological performance, the relationship between the degree of relatedness of M\&As and performance might be of a slightly different nature. With horizontal M\&As, we can expect that joint or complementary R\&D programs of the combined companies will generate new technologies in which both scale and scope effects seem to be beneficial to the technological performance of the merged companies. For vertical M\&As the expected effect on technological performance is probably somewhat less obvious and somewhat more speculative. Cost reduction by means of integrating upstream or downstream 'partners' could generate economic returns that can be partly reinvested in new technology programs. The integration of downstream user-firms can also help to identify market needs for new technologies, whereas the integration of upstream suppliers can benefit the introduction of new process and production technologies. ${ }^{22}$ Therefore, the vertical integration of users and suppliers can have a positive impact on the technological performance of companies. For unrelated M\&As, these effects of scope and scale economies are in general more difficult to materialize and the literature suggests that these M\&As are mainly intended to achieve financial synergies. This leads us to expect that the degree of relatedness of M\&As of both a horizontal or a vertical nature affects the technological performance of companies. (However, it has to be stressed that synergistic results of M\&As on which we focus in this paper are still dependent on positive financial economies in order to achieve the necessary interrelationships. In other words, without short-term economic results for M\&As, longterm results in technological performance may never materialize.)

Under these conditions, the above suggests the following hypothesis:

\section{H.1 There is a positive relationship between the relatedness of MEAs of companies and the technological performance of the combined companies.}

\section{Strategic Fit: Technological Relatedness of Companies Involved in MEAs}

So far, most of the debate on the strategic fit of companies involved in M\&As seems to focus on the industry-aspect of the relatedness of companies in terms of their productmarkets. As our research deals with the technological performance of M\&As, it seems appropriate to also consider the issue of technological relatedness of companies that enter into M\&As. Technological relatedness of companies, then, refers to the degree to which companies are active in particular fields of technology that they share with (potential) partners in M\&As. These fields of technology have to be understood in terms of the activities of companies related to relatively broad categories of technological disciplines 
and engineering capabilities, such as electronics, electrical engineering, chemistry, bioengineering and their sub-categories, that coincide with fields of technology as for instance identified by patent-classes. As with the line of reasoning for product-markets, we can expect that the more M\&As are established with companies from similar, horizontally related, fields of technology and also with technologically, vertically related companies, the higher the technological performance of the combined companies. Also here, synergies in scale and scope are the main reasons for expecting these different outcomes. Compared to technologically unrelated M\&As, the synergies and combined technological activities of related M\&As are expected to enable companies to shorten the innovation lead-time, share technological expertise and to engage in larger, combined projects than would be possible within the once separated companies.

Somewhat surprisingly, the literature on the strategic fit of companies involved in M\&As seems relatively silent on this particular topic. Jemison and Sitkin ${ }^{23}$ appear to only hint at the relevance of this aspect of strategic fit. Gerpott ${ }^{24}$ discusses technological fit in the context of the successful integration of different R\&D activities after an acquisition has taken place. Assuming that the successful integration of different R\&D activities leads to improved technological performance, his empirical findings suggest that the higher the degree of technology relatedness of companies involved in an M\&A, the more successful the M\&A will be. ${ }^{25}$ According to this line of thought for understanding the importance of technological relatedness of M\&As, following a similar logic as with product-market relatedness, we suggest that:

\section{H.2 There is a positive relationship between the technological relatedness of MEAs of companies and the technological performance of the combined companies.}

\section{Strategic Fit: Research Intensity of Companies Involved in MEAs}

The technological aspect of the strategic fit of M\&As, discussed in the previous section, covers the 'breadth' of the potential sharing of technological capabilities of companies across fields of technology. As far as the 'depth' of technological relatedness is concerned, i.e. the complementarity of their actual research effort, the question remains whether companies look for M\&A partners that have a similar or preferably a higher level of research activity. This strategic fit or depth of the technological relatedness expresses the attempt of M\&A-active companies to find technologically more advanced partners instead of technologically less advanced companies.

Early research suggests that companies in mature industries with low R\&D intensity appear to form M\&As with companies in R\&D-intensive industries in order to diversify into high-tech areas. ${ }^{26}$ However, MacDonald ${ }^{27}$ found no evidence of such dissimilarity. His research mainly indicates that $R \& D$ intensive firms aim at M\&As with companies from other $\mathrm{R} \& \mathrm{D}$ intensive sectors, that are similar in their $\mathrm{R} \& \mathrm{D}$ orientation in order to reach synergies in future $\mathrm{R} \& \mathrm{D}$. Hall ${ }^{28}$ also mentions the importance of synergistic motives for explaining M\&As in $R \& D$ intensive industries. She suggests that $R \& D$ intensive companies form M\&As with other R\&D intensive firms whether they are from similar or from different industries.

The above suggests that it is important to consider the effect of the R\&D intensity of M\&A partners on their combined technological output. Then, if one controls for the research intensity of the sectors in which M\&As take place, we can expect that M\&As with companies that have a higher $\mathrm{R} \& \mathrm{D}$ intensity than their sector average tend to lead to higher technological output. A major motive for M\&As with companies of higher $\mathrm{R} \& \mathrm{D}$ intensity is that these companies can be expected to have certain research 
capabilities and relevant skills that are future-oriented. This is probably important in a variety of industries but in particular in a high-tech environment where $\mathrm{R} \& \mathrm{D}$ capabilities are crucial for the further growth and development of companies. ${ }^{29}$ In other words, the 'depth' of this technological relatedness is found in the complementarity of more R\&D intensive M\&A partners that are instrumental in creating new knowledge through $R \& D$ that is expected to gradually improve technological performance. Contrary to this, M\&As with companies of lower R\&D intensity than their sector average will lead to lower technological performance of the combined companies. As the combined R\&D activity of these merged companies decreases, we can expect that a gradual erosion of the technological capabilities of these companies which will be translated into a decreasing technological performance. Hence:

\section{H.3 There is a positive relationship between the level of R\&D intensity of partner-companies in} $M E^{2} A s$ and the technological performance of the combined companies.

\section{Organizational Fit: Company Size and MEAs}

Although the concept of organizational fit between companies involved in M\&As covers a large number of aspects related to administrative routines and company-specific characteristics ${ }^{30}$ in our opinion similarities or differences in size of companies do, to a large extent, catch many aspects of organizational fit. Size of companies also relates to differences in organizational forms such as multi-divisional company structures and singledivisional companies that characterize differences between small and large companies. ${ }^{31}$ As a 'proxy' for organizational fit we can understand size of companies to express 'certain ways of doing business'. In other words, large companies have generally developed a completely different way of organizing themselves, for instance along divisional structures and other formal organizational routines, that is quite different from small and medium sized companies where informal structures are still most common. This not only applies to differences in general, but in particular to the different roles that large and small companies play with regard to technological development. ${ }^{32}$ This implies that M\&As between companies of different sizes have organizational consequences, in terms of the actual organizational fit of companies, that can affect the technological output after the M\&A has taken place. There is some evidence that the organizational differences between large and some small companies in the actual management of the innovation process are diminishing, ${ }^{33}$ but we expect that by and large these differences still exist. In particular, we can expect different procedures for $R \& D$ allocation and differences in strategic technology decision-making.

The empirical research seems to support this understanding of the differences in organizational fit between large and small firms. Chakrabarti, Hauschildt and Sueverkruep $^{34}$ found that combinations of large and small companies are confronted with organizational problems affecting technical success after the M\&A took place. Similarly, Gerpot $^{35}$ established that the size ratio of acquiring and acquired company affects the degree to which R\&D functions are successfully integrated after an M\&A. Smaller ratios (indicating a merger of companies that are close to being equal in size) are found to be related to more successful integration, whereas large size differentials within the M\&A generate major difficulties with integrating the $R \& D$ activities of M\&A partners.

What this part of the empirical literature suggests is that the lack of organizational fit between companies of different size classes has some serious consequences for the integration of the innovative activities of different M\&A partners. This seems to contradict a large part of the literature ${ }^{36}$ that suggests that the disparity between sizes of merging 
companies might be relatively easy to deal with in case of the integration of manufacturing, marketing and sales. However, in the complex world of non-routinized and specialized R\&D associated with specific technological capabilities, organizational integration aimed at technological performance might be more complex and more difficult to achieve than improved performance related to largely standard activities such as manufacturing and sales. ${ }^{37}$ This implies that, if companies are too far apart in terms of their size and related aspects of their organizational structure, the realization of improved technological performance after the M\&A might not be as simple as assumed on the basis of simple arithmetic. In other words, adding up the research and other technological activities of smaller partners to those of a large company, assuming that the integration process will take place rather smoothly, underestimates the organizational intricacies of such an M\&A between unequal partners. Hence:

\section{H.4 There is a positive relationship between the degree of similarity in terms of the size of companies involved in MEAs and the post-MEA technological performance of companies.}

\section{Methods}

\section{Sample}

The level of analysis in this study refers to the companies that are engaged in M\&As and not to individual M\&As. The main reason for this approach is that technological performance is generally measured at the level of the company and not at the level of an individual M\&A. In particular for a small acquisition the effect on the technological performance of each individual 'transaction' is difficult to trace, whereas the combined effect of a number of acquisitions of a company is detectable. Also, the registration of technological performance, e.g. through patents, usually takes place at the level of the company at large and not at the level of an acquired or merged unit.

As mentioned above, some previous research reveals that M\&As are expected to affect technological performance of companies, in particular in R\&D intensive industries. We chose companies in the international computer sector as the primary group for the analysis because of its high-tech character ${ }^{38}$ and the uncertainty that characterizes technological and economic development in this industry. In this study the computer industry consists of companies that produce mainframes and other computers, peripherals, CAD/CAM/CAE equipment, data communications equipment and other data processing products. The uncertainty surrounding the computer industry is well documented in a large number of popular publications and in the academic literature. ${ }^{39}$ These uncertain conditions are caused by endogenous technological change within the industry itself, the dependence on technological developments in the supplying micro-electronics and other components industries and the convergence of computer and telecom technologies which has led to lateral entry in both industries. ${ }^{40}$ The above implies that we analyze the effect of M\&As on the technological performance of these computer companies whereas the M\&As in which these companies are involved might of course be related to a variety of manufacturing industries. We excluded service related M\&As from the analysis, including software related M\&As. These service activities do generate technological development, however, they are also known to create few technical inventions in terms of codified knowledge that can only be partly measured by means of patents or similar indicators.

The above implies that, as in so many other somewhat comparable studies, we use a single-industry design, albeit with a choice for a large and international sector with a substantial number of M\&As, to control for potential industry effects. We study the effect 


\section{7. Hagedoorn $\mathcal{E}$ G. Duysters}

of a total number of 201 M\&As, made during the period 1986-1992, in a sample of 35 companies. Thirty of these companies have their headquarters in the USA, three companies are from Asian countries and two companies are European. These 35 companies (see Appendix 1) with M\&As, are taken from a total of 100 companies that account for more than $90 \%$ of the international computer market. ${ }^{41}$ In terms of market share, the $35 \mathrm{M} \& \mathrm{~A}$-active companies in our sample represent nearly $70 \%$ of the international computer market. The other 65 companies, all relatively small firms, did not have any M\&A during the period under investigation. Given the major differences between these sub-populations, in terms of the size of companies and their relevance to the computer industry, it is impossible to use the other sub-population as a control group.

\section{Variables}

We took the patent intensity growth of US patents of the companies in the sample from 1989 to 1994 as an indicator of the dependent variable technological performance. We use the number of patents that firms applied for in all IPC classes to measure their technological performance. As with so many other indicators, this patent indicator is subject to a debate regarding its bias and shortcomings. ${ }^{42}$ However, despite some shortcomings it is generally accepted as the most appropriate indicator that enables us to compare the technological performance of companies. ${ }^{43}$ Even authors that are critical of the overall use of patents as an indicator of technological performance or innovation, admit that they are appropriate in the context of the current, high-tech sector. ${ }^{44}$ Also, the less patents are used for cross-sectional analysis that ignores inter-sectoral differences in the propensity to patent, the better this indicator reflects the technological performance of companies.

As the size of companies will affect the technological performance of companies, as suggested by many studies, we will take the growth in 'patent intensity' (the ratio of the number of patents and total revenues) as the actual dependent variable.

The time-lag between M\&As and the change in technological performance covers an average period of six years (from the mean of the years for the independent variables, 1989 , to the final year for which the changes in technological performance is measured, 1994). According to Singh, and Buono and Bowditch ${ }^{45}$ it takes on average nearly five years before organizations are assimilated and gains of the M\&A are materialized. These studies, however, also indicate considerable variation in the assimilation process as some companies are able to unify their organizations within one year whereas it takes others substantially longer than the average of five years. According to Scherer, and Pakes and Griliches $^{46}$ it takes on average about one year before inventions through R\&D lead to patent applications. Taken together these two periods add up to an average time lag of about six years.

Given the degree of variance found for both the period of organizational assimilation and the effective time-span from $\mathrm{R} \& \mathrm{D}$ to patent application, as reported in previous research, we experimented with several alternative analyses. We used shorter intervals as well as different time lags, without compromising the size of the sample. The outcomes of these alternative analyses were similar to the results presented in this paper.

In the statistical analysis presented below we will apply the following independent variables:

Related and unrelated (conglomerate) MEAs are measured in terms of the (dis)similarity of the SIC code of the industries of M\&A partners at the three digit level. ${ }^{47}$ For related M\&As in the computer industry we constructed a list of related SICs (see Appendix II) based 
on a number of in-depth studies of the computer industry and related industries. ${ }^{48}$ This list of related SICs was presented to a small group of senior specialists from the computer industry who all confirmed that these industries are generally accepted as related industries. For each M\&A the SIC code of the target company was obtained through Securities Data's database on M\&As (see section on Data sources). The actual measure being used for each computer company in the sample is the share of its related M\&As as a percentage of all its M\&As.

Technologically related and technologically unrelated MEAs are measured in terms of the (dis)similarity of the patent classification (IPC) code of the patents owned by the M\&A partners at the three digit level. These patent classes represent the generally accepted perception of fields of technology by scientists and engineers to a similar degree as for instance industrial classes represent generally accepted classifications of industries by economists and management scholars. ${ }^{49}$ For technologically related M\&As we constructed a list of related IPCs (see Appendix 3). The same group of specialists from the computer industry that we consulted on industry relatedness confirmed that the patent classes taken to measure technological relatedness could be used to indicate the technological relatedness of M\&As. If the majority of the M\&A target's patents falls in related IPC classes, then the target company is considered to be technologically related. The actual measure for each company is the share of technologically related M\&As as a percentage of all its M\&As.

$R \& D$ intensity of $M E^{2} A$ partners is measured as the ratio of the $\mathrm{R} \& \mathrm{D}$ intensity of the M\&A partners, based on their average $R \& D$ expenditures of the two years before the $M \& A$, controlling for the average sector R\&D intensity. We calculated this variable as follows. We first assessed the R\&D intensity of each single firm against its industry average. If, e.g. a target company has a 1.5 higher $R \& D$ intensity than the industry average, the value of that ratio would be 1.5. Then, in order to arrive at one overall ratio for the combined set of M\&As we added up the ratios and divided this number by the number of M\&As. This overall ratio of the combined M\&As is divided by the ratio of the acquirer. This final measure is the value of the variable in the analysis. For example, if the acquirer has a ratio of 0.5 (half the intensity of the industry average) and the combined set of targets have a ratio of 1.5 then the value of this variable is 3 . The ratio of the acquired firm is three times higher than that of the acquiring firm, i.e. the ratio is 3 (1.5 divided by 0.5 . Thus, the higher the value of this measure, the higher the $R \& D$ intensity of the target(s) in comparison to the $\mathrm{R} \& \mathrm{D}$ intensity of the acquirer.

Similarity of size of MEA partners refers to the ratio of the size of both companies involved in the M\&A. Size is measured as the natural logarithm of total revenues in the year before the M\&A. Logarithms are taken to correct for a small number of very large companies. We divided the size of the acquiring firm by the size of the target firm. Because in all the cases the acquiring firm was the larger of the two, a lower ratio implies more similarity among the firms. The ratios of size for companies with a number of M\&As are also added up and divided by the number of their M\&As.

\section{Control Variables}

The RED intensity of the companies in the sample (1986-1992), i.e. R\&D expenditures as a share of total revenues, is taken as a control variable because we expect a direct effect of R\&D on patent activity as research efforts will (at least partly) be transformed into patents. In the literature the relation between $R \& D$ and patents has been studied 
extensively. Kamien and Schwartz ${ }^{50}$ have established that on average there is a direct relation between inventive effort or input and technological output. However, it is added that other factors can influence the transformation and the relation may not be linear. In some studies ${ }^{51}$ it is mentioned that patenting output decreases gradually with an increase of $\mathrm{R} \& \mathrm{D}$ expenditures.

Research on the effect of the internationalization of innovative activities through international MEAs suggests both positive and negative effects of this international diversification on technological performance, but the positive effects seem to be dominant. ${ }^{52}$ These positive effects are largely due to different local advantages generated by international $\mathrm{R} \& \mathrm{D}$ sourcing through acquired companies. Therefore, we will control for the international and domestic character of the M\&As of the companies in the sample. The international and domestic character of the M\&As of a company is determined by the share of international M\&As in the total number of its M\&As as registered according to the home country of the headquarters of companies during the period 1986-1992.

A third control variable that we introduce relates to the possible effect of experience with establishing of MEAs on the performance of M\&As. It is well known that one of the main problems for companies active in the field of M\&As is the difficult task of acquiring adequate information on target firms. It is obvious that, depending on the situation, target companies might have an incentive to somewhat misrepresent their innovative potential by overstating or understating their technological capabilities and the value of their research programs. This 'inspection problem' with M\&As or the problem of the possible lack of adequate information can be solved partially by experience as companies establish some routines and learning capabilities regarding the valuation of other companies. As suggested in the literature ${ }^{53}$ companies that have built up some experience in M\&As might find it easier to assess the value of target firms. Experience with the actual incorporation of the $\mathrm{R} \& \mathrm{D}$ programs of other companies in the overall technology strategy will also help to improve the post-M\&A performance. This suggests that experienced M\&A active firms have higher post-merger technological performance than inexperienced companies. Experience with M\&As is measured by taking the natural logarithm of the number of M\&As made during the seven years period from 1986 to 1992. We would have preferred a longer period or a period prior to the one for the other dependent variables but unfortunately there are no earlier international data available.

\section{Data Sources}

Data on M\&As for the period 1986-1992 is derived from a data bank owned by Securities Data, which we used via on-line access. This data bank contains information on worldwide M\&As. Within this database there is information on the year the M\&A was established and company information on the acquirer, the target, the parent acquirer and the parent target firm. The industry information is provided in SIC codes of the acquiree and acquirer.

Data for the size of companies and their R\&D expenditures is taken from several issues of Gartner Group's annual Yardstick top 100 worldwide covering a period from the early 1980s to the early 1990s. The Yardstick top 100 worldwide is an authoritative statistical review of the international computer industry comprising the top 100 computer companies. Data in the Yardstick was updated annually through surveys and research by Gartner Group consultants and industry analysts. When data was missing, estimates were taken from industry analyst input and from other available industry sources. The Yardstick contains calendar year information, not information based upon fiscal years, which allows 
us to make better comparisons between companies. Also, the Gartner data is adjusted for the effect of currency exchange rates.

We obtained additional data on $\mathrm{R} \& \mathrm{D}$, size and revenues of companies involved in M\&As through well-known databases such as Compustat, Disclosure and Worldscope. We used Dun and Bradstreet's Global Linkages to track the subsidiaries of each company in our sample in order to include patents that were filed by some of these subsidiaries.

The data on patents for the dependent variable (technological performance) is taken from the US Patent and Trademark Office database (US Department of Commerce). Although this US data could imply a bias in favour of US companies and against nonUS firms, the group of non-US companies in this sample represents a group of innovative and rather large firms that are known to patent worldwide. Furthermore, the literature suggests several other reasons to take US patents as an indicator. Frequently mentioned are the importance of the US market, the 'real' patent protection offered by US authorities, the level of technological sophistication of the US market which makes it almost compulsory for non-US companies to file patents in the USA. ${ }^{54}$

\section{Analysis}

In order to test the hypotheses we applied a standard ordinary least square regression model (see Table 2). The correlations in Table 1 do not suggest multi-collinearity. However, given the relatively high $R^{2}$ of the model we undertook some additional tests to detect possible multi-collinearity. We regressed each independent variable on all the other independent variables ${ }^{55}$ - this test did not indicate multi-collinearity. In addition, we used a number of other multi-collinearity diagnostics, taking a closer look at VIF and Tolerance value statistics, which also did not detect any signs of multi-collinearity.

Table 2 demonstrates that hypothesis 1 is supported as our analysis generates a significant, positive relationship between the degree to which companies use related M\&As and their technological performance. Hypothesis 2, which concerns technological relatedness, is also supported as we found a statistically significant and positive effect of these technologically related M\&As on the technological performance of companies. Our other results show that the acquisition and merging of companies with higher $\mathrm{R} \& \mathrm{D}$ intensity significantly improves the technological performance of the acquiring firm (hypothesis 3 is confirmed). Also, the expected relationship between the degree of similarity in terms of the size of companies involved in M\&As and the technological performance of the acquiring firms (hypothesis 4) was indeed established in our analysis (lower scores are associated with greater similarity).

The control variable for the R\&D intensity of companies seems to have a significant, albeit negative, impact on the improved technological performance of companies. This indicates that, as already found in other contributions discussed in the above, patenting output decreases with an increase of $\mathrm{R} \& \mathrm{D}$ expenditures. In other words, an increase in R\&D intensity of companies does not imply a parallel growth in technological performance. Our findings for the second control variable suggest that, as found in some previous research, international M\&As improve the technological performance of companies. However, extensive experience of companies with M\&As does not seem to influence their technological performance.

\section{Discussion}

Our analysis demonstrates that major aspects of the strategic and organizational fit of companies engaged in M\&As seem important for generating improved technological 
78 7. Hagedoorn $\mathcal{E}$ G. Duysters

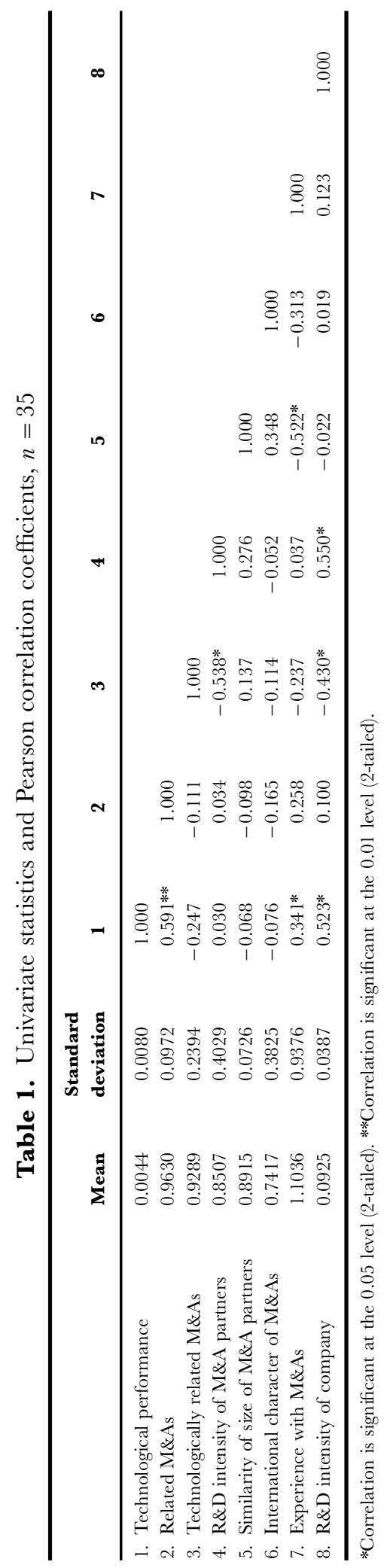


Table 2. Regression estimates of the influence of M\&As (1986-1992) on the technological performance of companies (growth of patent intensity, 1989-1994) in the international computer industry, $n=35$

\begin{tabular}{lcc}
\hline Variables & Beta & $\boldsymbol{T}$ \\
\hline Constant & & -1.15 \\
Related M\&As & 0.607 & $4.88^{* * * *}$ \\
Technologically related M\&As & 0.293 & $1.80^{*}$ \\
R\&D intensity of M\&A partners & 1.056 & $5.68^{* * *}$ \\
Similarity of size of M\&A partners & -0.362 & $-2.16^{* *}$ \\
International character of M\&As & 0.306 & $2.17^{* *}$ \\
Experience with M\&As & 0.186 & 1.26 \\
R\&D intensity of company & -0.522 & $-3.53^{* * * *}$ \\
\hline
\end{tabular}

$* p<0.10 ; * * p<0.05 ; * * * p<0.01$.

$R^{2}=0.888 ;$ Adj $R^{2}=0.790 ;$ Std Error $=0.00537 ; F=9.064$; Sign. $F=0.003$.

Regression $(\mathrm{df})=7$; error $(\mathrm{df})=28$; Total $(\mathrm{df})=35$.

performance in an international high-tech environment. Our findings suggest that the strategic fit between companies in related product markets increases the innovative potential of M\&As. This finding adds additional support to much of the empirical evidence of previous research on the economic performance of M\&As that indicates that related diversification through $M \& A s$ is more beneficial to companies than unrelated diversification. ${ }^{56}$ The role of this particular aspect of the strategic fit of companies in explaining performance improvement supports much of the conventional wisdom from, for example, economics regarding the economies of scale and scope that companies can achieve when they expand into related activities. The strategic fit of M\&As in terms of broad product-market categories seems to generate a baseline for joint activities that secures the overall relevance of the M\&As to the improved performance of the combined companies. However, it is important to note that this aspect of the strategic fit is still largely related to the existing activities of companies, whereas the technological capabilities of merging companies are expected to be also dependent on future-oriented technological aspects of their strategic fit.

It appears that linking up to more $\mathrm{R} \& \mathrm{D}$ intensive companies generates strong results in terms of higher technological performance. We recall that some of the older literatures ${ }^{57}$ already indicated that M\&As with $\mathrm{R} \& \mathrm{D}$ intensive firms would enable acquiring companies to increase control over high-tech environments that are relevant to them. When companies establish M\&As with other companies of higher R\&D intensity, this implies that they are integrating partners that are more likely to be engaged in new activities, which adds to the formation of new capabilities and learning skills within the new entity. In other words, these R\&D intensive M\&As are instrumental to the more general process of exploratory learning ${ }^{58}$ and they play an important role in the improvement of technological competencies that are crucial for companies to remain competitive in a high-tech environment. ${ }^{59}$

It is obvious that the 'depth' of the technological relatedness of M\&As, i.e. the complementarity in higher R\&D efforts, affects the increased R\&D potential of the combined companies. When companies engage in M\&As with companies with higher $\mathrm{R} \& \mathrm{D}$ inputs, the M\&As are expected to be future oriented as the increased $\mathrm{R} \& \mathrm{D}$ intensity of these companies focuses on the search for new technologies, products and processes. These R\&D increasing M\&As have a long term, strategic effect that we found to lead to improved technological performance of the combined companies. 
The effect of technologically related M\&As is only marginally significant and the statistical support is weaker than for the other variables. In that context it is important to note that there is considerable chance of duplication of existing technological capabilities, with a similar 'breadth' of technological relatedness of companies, when they only share broad patenting profiles based on previous technological achievements. In that case, there could be fewer learning opportunities and companies could have more difficulty engaging in new activities and developing new technological capabilities that will lead to improved technological performance. In other words, unlike the 'depth' of technological relatedness, the 'breadth' of technological relatedness of M\&As merely reflects the status quo of the technological capabilities of companies and this expansion through technologically similar M\&As can be expected to only have a marginal effect on the improved technological performance of firms. Combining companies with similar technological capabilities and a somewhat similar technological track record merely duplicates existing capabilities that only have a limited impact on the future technological performance of the combined companies. ${ }^{60}$

The organizational fit of companies, their similarity in size, which we found to be important to explain improved technological performance, seems to benefit the actual integration process of merging companies. Previous research ${ }^{61}$ already mentioned that large differences in size of companies indicate dissimilarities in the organizational setting of partners, which might frustrate the actual post-merger integration process. From the perspective of the technological performance of M\&As, our research shows that a large difference in size of companies, indicating a poor organizational fit, generates weaker performance than in the case of greater organizational similarity of partners. The popular business literature provides many examples from high-tech industries (in particular biotechnology, software, microelectronics and computers) where large companies have great difficulty in integrating small companies with a different 'culture' while keeping key-employees from these acquisitions 'on board'.

Although not directly related to the effect of strategic and organizational fit on the technological performance of companies, our research suggests some interesting results for international M\&As and the effect of experience with M\&As on technological performance. It appears that companies that have a preference for international M\&As, that benefit from several international $R \& D$ sources and from different regionally concentrated technological competencies, improve their technological performance. As discussed in the above this highlights the importance of international learning through M\&As as being very important for companies in a high-tech environment that has also become highly internationalized. ${ }^{62}$

Somewhat surprisingly, we found no clear evidence of the positive effect of the experience of companies through a larger number of M\&As. Increasing the number of M\&As does not seem to necessarily improve the performance of companies in a linear way. However, most companies in this sample have some experience with M\&As as they made more than one M\&A in a few years. What this finding does indicate is that, if there is an experience effect regarding M\&As at all, the effect of increased experience would most probably wear off beyond a rather low threshold. Also, as suggested by Hitt et al. ${ }^{63}$ for companies to learn from their M\&As, the sheer number of M\&As could be less decisive than their effective learning capability with regard to M\&As and other external sources of innovation.

\section{Conclusions}

Our study focuses on a single, high-tech industry, albeit a large one and with an international population consisting of a variety of companies, that are studied for a period 
of nearly a decade. As our results might reflect some industry and period-specific factors, elaboration of the study in different settings could generate useful additional insights. With this caveat in mind, we can draw the following conclusions.

Our research demonstrates that M\&As can contribute to improving the technological performance of companies in a high-tech environment. However, it has to be stressed that both the organizational and the strategic fit of the companies involved in these M\&As are crucial for the technological success of M\&As. These critical factors were already discussed in some earlier contributions that concentrated mainly on the general effect of M\&As on economic performance and profitability. Not only does our current research establish the important role that organizational and strategic fit seem to also have for the technological performance of M\&A-active companies, it in particular emphasizes the importance of linking-up with more research-intensive companies. This suggests that the acquisition of these companies, through which the acquiring company can improve its technological skills and expected learning capabilities, has a positive effect on the technological performance of acquiring companies after M\&As have taken place.

The current contribution does not investigate the short-term economic benefits of M\&As but it concentrates on the technological performance of companies that might have long-term strategic consequences, eventually leading to increased economic performance. In that context the M\&As can be interpreted as an attempt of companies to increase both control over their environment in order to respond to uncertainty and to improve their performance. The successful integration of other companies in a familiar environment and the search for new opportunities through M\&As are both mentioned in that context as major mechanisms in a two-fold strategy to improve technological performance. The relevance of market relatedness of M\&As stresses the importance of uncertainty reduction by means of integration of companies that are active in similar sectors and that have some similarity in terms of product-markets. The integration of R\&D intensive companies, however, creates the necessary new skills and capabilities that enable the company to learn about new perspectives that can decrease its dependency on its existing environment and improve its performance. Therefore, the external acquisition of technological capabilities by means of M\&As can, if proper attention is paid to the strategic and organizational fit of companies, prove to be an important strategic advantage for companies in high-tech sectors.

\section{Notes and References}

A substantial part of this research was undertaken while John Hagedoorn was visiting the Haas School of Business, University of California at Berkeley, and the Center for International Science and Technology Policy at The George Washington University, Washington DC. The authors thank participants at seminars at the University of California at Berkeley, University of Groningen, Technological University Eindhoven, and Rene Belderbos, Bruce Heiman, Mike Hitt, Hans van Kranenburg, Al Link, David Mowery, Bart Verspagen and anonymous referees of this journal for their comments on a preliminary version of the paper.

1. R.E. Caves, 'Mergers, Takeovers, and Economic Efficiency - Foresight vs. Hindsight', International Fournal of Industrial Organization, 7, 1989, pp. 150-172; A.D. Cosh, A. Hughes, K. Lee \& A. Singh, 'Institutional Investment, Mergers and the Market for Corporate Control', International fournal for Industrial Organization, 7, 1989, pp. 73-101; D.C. Mueller, The Modern Corporation-Profits, Power, Growth and Performance (Brighton, Wheatsheaf, 1986); D.J. Ravenscraft \& F.M. Scherer, 'Life after Takeover', Journal of Industrial Economics, 36, 1987, pp. 147-157; F.M. Scherer, 'Corporate Takeovers: The Efficiency Arguments', Journal of Economic Perspectives, 2, 1988, pp. 68-83. 
2. H. Odagiri \& T. Hase, 'Are Mergers and Acquisitions Going to be Popular in Japan, Too? An Empirical Study', International fournal of Industrial Organization, 7, 1989, pp. 49-73; J. Scott, Purposive Diversification and Economic Performance (Cambridge, Cambridge University Press, 1993).

3. R.R. Rumelt, Strategy, Structure, and Economic Performance (Boston, MA, Harvard Business Press, 1974).

4. M.A. Hitt, J. Harrison, R.D. Ireland \& A. Best, 'Attributes of Successful and Unsuccessful Acquisitions of US Firms', British fournal of Management, 19, 1998, pp. 91-114; J.B. Kusewitt, Jr, 'An Exploratory Study of Strategic Acquisition Factors Relating to Performance', Strategic Management Fournal, 6, 1985, pp. 151-169; M. Lubatkin, 'Merger Strategies and Stockholder Value', Strategic Management fournal, 8, 1987, pp. 39-53; C.A. Montgomery \& V.A. Wilson, 'Mergers that Last: A Predictable Pattern', Strategic Management Journal, 7, 1986, pp. 91-96; H. Singh and C.A. Montgomery, 'Corporate Acquisition Strategies and Economic Performance', Strategic Management Journal, 8, 1987, pp. 377-386.

5. A.N. Link, 'Acquisitions as Sources of Technological Innovation', Mergers and Acquisitions, 23(3), 1988, pp. 36-39.

6. A. Chakrabarti, J. Hauschildt \& C. Sueverkruep, 'Does it Pay to Acquire Technological Firms?', REDD Management, 24, 1994, pp. 47-56; T.J. Gerpott, 'Succesful Integration of R\&D Functions after Acquisition: An Exploratory Empirical Study, RED Management, 25, 1995, pp. 161-178; O. Grandstrand, E. Bohlin, C. Oskarsson \& N. Sjoberg, 'External Technology Acquisition in Large Multi-technology Corporations', RED Management, 22, 1992, pp. 111-133; M.A. Hitt, R.E. Hoskisson, R.D. Ireland \& J.S. Harrison, 'Effects of Acquisitions on R\&D Inputs and Outputs', Academy of Management Journal, 34, 1991, pp. 693-706.

7. Chakrabarti et al., op. cit., Ref. 6.

8. Schumpeter, Capitalism, Socialism and Democracy (New York, Harper Torchbooks, 1942).

9. Chakrabarti, et al., op. cit., Ref. 6; M.A. Hitt, R.E. Hoskisson, R.A. Johnson \& D.D. Moesel, 'The Market for Corporate Control and Firm Innovation', Academy of Management Journal, 39, 1996, pp. 1084-1119; K. Ikedo \& N. Doi, 'The Performance of Merging Firms in Japanese Manufacturing Industry: 1964-1975', Journal of Industrial Economics, 31, 1983, pp. 257-266; S.M. Oster, Modern Competitive Analysis (New York, Oxford University Press, 1994).

10. H.W. de Jong, 'Theory and Evidence Concerning Mergers: An International Comparison', in: A.P. Jacquemin \& H.W. de Jong (Eds), Markets, Corporate Behaviour and the State (The Hague, Nijhoff, 1976), pp. 95-123.

11. A.K. Chakrabarti \& J. Burton, 'Technological Characteristics of Mergers and Acquisitions in the 1970's in Manufacturing Industries in the US', Quarterly Review of Economics and Business, 23, 1983, pp. $81-90$.

12. Grandstrand et al., 1992, op. cit., Ref. 5; Link, op. cit., Ref. 5; J.M. MacDonald, 'R\&D and the Directions of Diversification', Review of Economics and Statistics, 47, 1985, pp. 583-590.

13. J. Pfeffer, 'Merger as a Response to Organizational Interdependence', Administrative Science Quarterly, 17, 1972, pp. 382-394; C.J. Sutton, Economics and Corporate Strategy (Cambridge, Cambridge University Press, 1980); O.E. Williamson, The Mechanisms of Governance (Oxford, Oxford University Press, 1996).

14. Pfeffer, op. cit., Ref. 13.

15. Link, op. cit., Ref. 5; MacDonald, op. cit., Ref. 12.

16. H.G. Barkema \& F. Vermeulen, 'International Expansion Through Start-up or Acquisition: A Learning Perspective', Academy of Management Journal, 41, 1998, pp. 7-26; M. Dodgson, 'Organizational Learning: A Review of some Literatures', Organization Studies, 14, 1993, pp. 375-394.

17. D.K. Datta, 'Organizational Fit and Acquisition Performance: Effects of Post-acquisition Integration', Strategic Management Journal, 12, 1991, pp. 281-297; Hitt et al., op. cit., Ref. 4; D.B. Jemison \& S.B. Sitkin, 'Corporate Acquisitions: A Process Perspective', Academy of Management Review, 11, 1986, pp. 145-163.

18. Datta, op. cit., Ref. 17.

19. Montgomery \& Wilson, op. cit., Ref. 4.

20. Datta, op. cit., Ref. 17; Kusewitt, op. cit., Ref. 4; Oster, op. cit., Ref. 9; M.E. Porter, 'From Competitive Advantage to Corporate Strategy', Harvard Business Review, May-June 1987, pp. 43-59; Singh \& Montgomery, op. cit., Ref. 4.

21. Datta, op. cit., Ref. 17. 
22. G. Freeman \& L. Soete, The Economics of Industrial Innovation (London, Pinter, 1997).

23. Jemison \& Sitkin, op. cit., Ref. 17.

24. Gerpott, op. cit., Ref. 6.

25. Ibid.

26. Chakrabarti \& Burton, op. cit., Ref. 11.

27. MacDonald, op. cit., Ref. 12.

28. B.H. Hall, 'The Impact of Corporate Restructuring on Industrial Research and Development', Brookings Papers on Economic Activity, 3, 1990, pp. 85-135.

29. Freeman \& Soete, op. cit., Ref. 22; R. Henderson \& I. Cockburn, 'Measuring Competence: Exploring Firm-effects in Pharmaceutical Research', Strategic Management Journal, 15, Special Issue, Winter 1994, pp. 63-84.

30. Datta, op. cit., Ref. 17; Jemison \& Sitkin, op. cit., Ref. 17.

31. A.D. Chandler, Scale and Scope: The Dynamics of Industrial Capitalism (Cambridge, MA, Harvard University Press, 1990).

32. G. 1990, 'Sources, Procedures, and Microeconomic Effects of Innovation', Fournal of Economic Literature, 26, 1988, pp 1120-1171; Freeman \& Soete, op. cit., Ref. 22.

33. T. Haggblom, R.J. Calantone \& C.A. Di Benedetto, 'Do New Product Development Managers in Large or High-market-share Firms Perceive Marketing-R\&D Interface Principles Differently', Journal of Product Innovation Management, 12, 1995, pp. 323-333.

34. Chakrabarti et al., op. cit., Ref. 6.

35. Gerpott, op. cit., Ref. 6.

36. P. Haspeslagh \& D. Jemison, Managing Acquisitions: Creating Value Through Corporate Renewal (New York, Free Press, 1991); R.E. Hoskisson \& M.A. Hitt, Dowenscoping - How to Tame the Diversified Firm (New York, Oxford University Press, 1994); Jemison \& Sitkin, op. cit., Ref. 17.

37. R.R. Nelson \& S.G. Winter, An Evolutionary Theory of Economic Change (Cambridge, MA, Belknap Press, 1982).

38. OECD, Revision of High Technology Sector and Product Classification (Paris, OECD, 1997).

39. G. Duysters, The Dynamics of Technical Innovation (Cheltenham, Edward Elgar, 1996); J.M. Harper, Telecommunications and Computing: The Uncompleted Revolution (London, Communications Educational Series, 1996); P. Korzeniowski, 'Partners to be Part of IBM's Future', Communication Week, 28 March 1988; F. Malerba, S. Torrisi \& N. von Tunzelmann, 'Electronic Computers', in: C. Freeman, M. Sharp \& W. Walker (Eds), Technology and the Future of Europe: Global Competition and the Environment in the 1990s (London, Pinter, 1991); R. Mansell, The New Telecommunications: A Political Economy of Network Evolution (Newbury Park, Sage, 1993); D.E. Raphael, The Changing Structure of the Global Information Industry, SRI International, Report No. 807, 1989.

40. G. Duysters \& J. Hagedoorn, 'Technological Convergence in the IT Industry', International fournal of the Economics of Business, 5, 1998, pp. 355-368.

41. Gartner Group, Yardstick Top 100 Worldwide (Stamford, Gartner Group, 1994).

42. D. Archibugi, 'Patenting as an Indicator of Technological Innovation: A Review', Science and Public Policy, 6, 1992, pp. 357-358; W.M. Cohen \& R.C. Levin, 'Empirical Studies of Innovation and Market Structure', in: R. Schmalensee \& R. Willig (Eds), Handbook of Industrial Organization, Vol. 2 (Amsterdam, Elsevier, 1989), pp. 1059-1107; Griliches, op. cit., Ref. 42.

43. Z.J. Acs \& D.B. Audretsch, 'Patents as a Measure of Innovative Activity, Kyklos, 4, 1989, pp. 171-180; H. Aspden, 'Patent Statistics as a Measure of Technological Vitality', World Patent Information, 5, 1983, pp. 170-173; H. Bresman, J. Birkenshaw \& R. Nobel, 'Knowledge Transfer in International Acquisitions', Fournal of International Business Studies, 30, 1999, pp. 439-462; E. Brouwer \& A. Kleinknecht, 'Innovative Output, and a Firm's Propensity to Patents-An Exploration of CIS Micro Data', Research Policy, 28, 1999, pp. 615-624; J. Cantwell \& C. Hodson, 'Global R\&D and UK Competitiveness', in: M. Casson (Ed.), Global Research Strategy and International Competitiveness (Blackwell, Oxford, 1991), pp. 133-182; T.M. Devinney, 'How Well do Patents Measure New Product Activity?', Economic Letters, 41, 1993, pp. 447-450; Freeman \& Soete, op. cit., Ref. 22; Griliches, op. cit., Ref. 42; G. Napolitano \& G. Sirilli, 'The Patent System and the Exploitation of Inventions: Results of a Statistical Survey Conducted in Italy', Technovation, 10, 1990, pp. 5-16; P. Patel \& K. Pavitt, 'Divergence in Technological Development Among Countries and Firms', in: J. Hagedoorn (Ed.), Technical Change and the World Economy - Convergence and Divergence in Technology 
Strategies (Aldershot, Edward Elgar, 1995), pp. 147-181; K. Pavitt, 'Uses and Abuses of Patent Statistics', in: A.F.J. van Raan, Handbook of Quantitative Studies of Science and Technology (Amsterdam, Elsevier, 1988).

44. A. Arundel \& J. Kabla, 'What Percentage of Innovations are Patented? Experimental Estimates in European Firms', Research Policy, 27, 1998, pp. 127-142; E. Mansfield, 'Patents and Innovation: An Empirical Study', Management Science, 32, 1986, pp. 173-181.

45. A. Singh, 'Take-overs', University of Cambridge Department of Applied Economics, Monograph 19 (Cambridge, Cambridge University Press, 1971); A.S.F. Buono \& J.L. Bowditch, The Human Side of Mergers and Acquisitions (San Francisco, Jossey-Bass, 1989).

46. F.M. Scherer, 'Using Linked Patent and R\&D Data to Measure Interindustry Technology Flows', in: Z. Griliches (Ed.), RED, Patents and Productivity (Chicago, The University of Chicago Press, 1984), pp. 417-464; A. Pakes \& Z. Griliches, 'Patents and R\&D at the Firm Level; A First Look', in: Z. Griliches (Ed.), RED, Patents and Productivity (Chicago, The University of Chicago Press, 1984), pp. 55-72.

47. Kusewitt, op. cit., Ref. 4 .

48. Duysters, op. cit., Ref. 39; Harper, op. cit., Ref. 39; Malerba et al., op. cit., Ref. 39; Mansell, op. cit., Ref. 39.

49. Z. Griliches, 'Patent Statistics as Economic Indicators: A Survey', Journal of Economic Literature, 28, pp. 1661-1697.

50. M.I. Kamien \& N.L. Schwartz, Market Structure and Innovation (Cambridge, Cambridge University Press, 1982).

51. J. Bound, C. Cummins, Z. Griliches, B.H. Hall \& A. Jaffe, 'Who Does R\&D and Who Patents?', in: Z. Griliches (Ed.), RED, Patents, and Productivity (Chicago, University of Chicago Press, 1984), pp. 21-54; F.M. Scherer, Innovation and Growth: Schumpeterian Perspectives (Cambridge, MIT Press, 1984); J. Hausman, B.H. Hall \& Z. Griliches, 'Econometric Models for Count Data with an Application to the Patents-R\&D Relationship', Econometrica, 52, 1984, pp. 909-938.

52. C. Freeman \& J. Hagedoorn, 'Convergence and Divergence in the Internationalization of Technology', in: J. Hagedoorn (Ed.), Technical Change and the World Economy-Convergence and Divergence in Technology Strategies (Aldershot, Edward Elgar, 1995), pp. 34-57; Hoskisson \& Hitt, op. cit., Ref. 36.

53. Hitt et al., op. cit., Ref. 4; Oster, op. cit., Ref. 9.

54. See P. Patel \& K. Pavitt, 'Large Firms in the Production of the World's Technology: An Important Case of Non-globalization', fournal of International Business Studies, 22, 1991, pp. 1-21, for a discussion on the use of US patent data.

55. M.S. Lewis-Beck, Regression Analysis (London, Sage, 1993).

56. Oster, op. cit., Ref. 9; Porter, op. cit., Ref. 20; Singh \& Montgomery, op. cit., Ref. 4.

57. Link, op. cit., Ref. 5; MacDonald, op. cit., Ref. 12.

58. Dodgson, op. cit., Ref. 16.

59. Haspeslagh \& Jemison, op. cit., Ref. 36; Hitt et al., op. cit., Ref. 4.

60. Hitt et al., op. cit., Ref. 4.

61. Chakrabarti et al., op. cit., Ref. 6; Gerpott, op. cit., Ref. 6.

62. Barkema \& Vermeulen, op. cit., Ref.16.

63. Hitt et al. op. cit., Ref. 4. 


\section{Appendix 1. Companies in the Analysis}

$\begin{array}{lll}\text { 3Com } & \text { Exabyte } & \text { Network Systems } \\ \text { Acer } & \text { Fujitsu } & \text { Olivetti } \\ \text { Apple } & \text { General DataComm } & \text { Recognition Equipment } \\ \text { AST Research } & \text { Genicom } & \text { Seagate } \\ \text { Cadence } & \text { Gerber Scientific } & \text { Sequent } \\ \text { Compaq } & \text { Groupe Bull } & \text { Silicon Graphics } \\ \text { Conner } & \text { IBM } & \text { Storage Tech } \\ \text { Control Data Systems } & \text { Intergraph } & \text { Sun Microsystems } \\ \text { Cray Research } & \text { Maxtor } & \text { Tandem } \\ \text { Data General } & \text { Mentor Graphics } & \text { Unisys } \\ \text { Digital Equipment } & \text { National Computer Systems } & \text { Wang } \\ \text { Digital Communications } & \text { NEC } & \end{array}$

\section{Appendix 2. Related and Unrelated M\&As According to SIC Codes of Partners}

Related M\&As are between companies that are both found in the following SIC classes:

357. Computer and office equipment

366. Communications equipment

367. Electronic components and accessories

369. Miscellaneous electrical machinery, equipment and supplies (batteries, disk, tape)

382. Measuring and controlling devices

All other cases refer to unrelated M\&As.

\section{Appendix 3. Technologically Related and Unrelated M\&As According to Patent Glassification of Patents of Partners}

Technologically related M\&As are between companies of which the patents correspond with the following IPG classes:

Seq. No.

(IPC code) Description

\begin{tabular}{ll}
\hline 27 & Office computing and accounting machines \\
40 & Miscellaneous electrical machinery, equipment and supplies \\
43 & Electronic components and accessories and communications equipment \\
55 & Professional and scientific instruments \\
\hline
\end{tabular}

All other cases refer to technologically unrelated M\&As. 